\title{
Doença de Alzheimer e vida religiosa consagrada: uma etnografia de afeto e espanto
}

\author{
LETICIA VICENTIN \\ Universidade Estadual de Campinas, Campinas | SP, Brasil \\ leticia.vicentin@hotmail.com
}

DOI 10.11606/issn.2316-9133.v30i7pe172927

resumo Este trabalho buscou compreender como a vida religiosa consagrada influencia nos modos pelos quais um grupo de Irmãs católicas percebe e vive a doença de Alzheimer. O objetivo foi acompanhar a ontologia múltipla da doença sendo feita, no cotidiano, através das práticas, afetos e silêncios na Residência em que moram. A valorização do pós-morte e da trajetória religiosa traz interpretações próprias para a enfermidade, dissolvendo alguns temores e acolhendo sintomas. Ao articular duas vertentes analíticas - corporeidade e selfhood-, busco apreender como esses corpos em processo demencial percebem o mundo e atravessam a experiência com a doença quando inseridos em um contexto religioso, e como o meu próprio corpo se deslocou em campo. Mostro também como as imagens - fotografias e desenhos - foram importantes para entrar no mundo tanto da demência quanto da vida consagrada, a fim de ver e ouvir o que os silêncios não me deixaram encontrar, no início.

palavras-chave Doença de Alzheimer. Vida religiosa consagrada. Corpo. Imagem. Etnografia

\footnotetext{
Alzheimer's disease and consecrated life: an ethnography of affect and astonishment

abstract This study sought to understand how consecrated life influences the way a group of catholic nuns perceive and live Alzheimer's disease. The goal was to monitor the multiple ontologies of the disease being built in day-by-day life through the practices, affections, and silence in the residence where they live. The appreciation of the afterlife and religious path brings their own interpretations of the disease, undoing fears and embracing symptoms. By means of two analytical approaches, namely embodiment and selfhood, it attempts to apprehend how these bodies in the process of dementia perceive the world and undergo the experience with the disease in a religious context and how my own body also shifted in the field. I also show
} 
how images - photographs and drawings - held a crucial role to gain entrance to the world of dementia and consecrated life in order to see and listen that which the silence did not allow me to find in the beginning.

keywords Alzheimer's disease. Consecrated life. Body. Image. Ethnography

\section{La enfermedad de Alzheimer y la vida religiosa consagrada: una etnografía hacia el afecto y el asombro \\ resumen $\mathrm{El}$ artículo busca comprender cómo la vida religiosa consagrada influye en} la forma en que un grupo de hermanas católicas percibe y vive la enfermedad de Alzheimer. El objetivo era seguir la ontología múltiple de la enfermedad que se hace, en la vida cotidiana, a través de las prácticas, los afectos y los silencios en la Residencia donde viven. La valorización del más allá y la trayectoria religiosa aportan sus propias interpretaciones a la enfermedad, disolviendo algunos miedos y acogiendo síntomas, en una relación entre enfermedad, vejez, cuidados, género y religión. Mediante la articulación de dos vertientes analíticas -corporalidad y selfhood-, se busca aprehender cómo estos cuerpos en proceso de demencia perciben el mundo y atraviesan la experiencia con la enfermedad cuando se insertan en un contexto religioso, y cómo mi propio cuerpo fue desplazado en el campo. Por último, muestro cómo las imágenes fotografías y dibujos- fueron importantes para entrar en el mundo tanto de la demencia como de la religión, para ver y escuchar lo que los silencios no me dejaban encontrar al principio. palabras clave Enfermedad de Alzheimer. Vida religiosa consagrada. Cuerpo. Imagen. Etnografía

\section{Introdução}

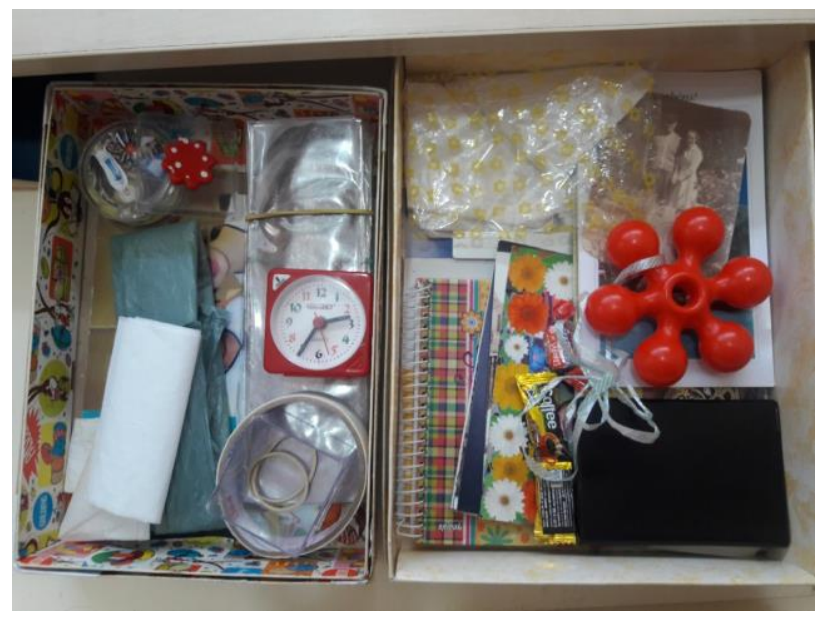

Figura 1. A gaveta de Anastásia. Fonte: A Autora (2019) 
Irmã Anastásia se foi ontem. E compreender sua ida e aceitá-la de coração confortado é um dos maiores desafios para mim desde que as conheci. Digo "desafio" porque essas mulheres veem a morte como um não-fim. E eu estou tentando sentir a fundo que a vida delas é feita na abertura do devir, no movimento. Anastásia me entregava guardanapos de papel de presente e dividia comigo suas leituras incansáveis nos livrinhos da liturgia. Fez-me adentrar seu mundo avesso, me mostrou suas gavetas e suas bolachas entre páginas da revista. Disse que nós vivíamos juntas há anos e refez quem eu era. Permitiu que eu fosse Irmã, cuidadora, sua aluna. Acolheu-me como pesquisadora e me forçou a mudar minhas técnicas metodológicas diversas vezes, talvez sem saber, até eu perceber que a atenção ao movimento e o espanto à possibilidade daquele mundo só se abriria para mim dessa forma. Irmã Anastásia gostava dos meus lenços de tecido e ria quando me via sentar no chão para escrever anotações no meu caderno de campo. Irmã Anastásia me deu balas de já alguns meses e eu as guardei como se fossem tesouros, assim como ela fazia, como se todos os dias fossem pequenos e novos embrulhos brilhantes a serem descobertos, assim como ela descobria, espantada, as bolachas na revista e seus retratos que nem sempre eram seus. Irmã Anastásia disse que iríamos nos ver quando eu voltasse ao campo. E como outras coisas que ela se esqueceu, não lembrou de me confessar que aquela era a última vez. Sua gaveta, suas composições e dobras perfeitas sempre me deixaram encantada. Obrigada pelo mundo que me permitiu conhecer. (Registros de campo, 15/08/2019, Carta de despedida à Irmã Anastásia).

Essa foi uma carta de despedida que escrevi para a Anastásia, uma das Irmãs da Residência Carmen Sallés, em São Paulo, já quando estava longe do campo e soube de sua morte. Ela, assim como um grupo de outras 6 mulheres dentre 13, recebeu o diagnóstico para doença de Alzheimer (DA). Vivi com elas, entre dois anos de pesquisa, por cerca de 50 dias. ${ }^{1}$ Nos últimos dias de campo, a morte da Anastásia, que se aproximava devido às complicações da doença, era a mais comentada. "Será que ela tem medo de morrer?", uma dizia. "Não precisa segurar a vida", outra completava.

A razão pela qual eu tentava compreender esse não-fim delas com um assombro reverente (Sacks, 1997) é que essa etnografia se permitiu ao espanto e ao afeto (Favret-Saada, 2009; Ingold, 2015). Nesse percurso, deparei-me com mulheres que percebem a morte como a abertura para a continuidade e o devir, marcada pelo desprendimento da alma que encontra a

\footnotetext{
${ }^{1}$ Pesquisa de Iniciação Científica realizada entre os anos 2017 e 2019 na Universidade Estadual de Campinas com orientação de Guita Grin Debert e Daniela Moreno Feriani A pesquisa foi autorizada pelo Comitê de Ética em Pesquisa CAAE:80188817.1.0000.8142.
} 
eternidade em um lugar - outro junto ao transcendente cristão (Robbins, 2011). A valorização desse devir pós-morte e a noção de que os resultados da trajetória da vida religiosa não são perdidos contribuem para novas possibilidades de percepção da doença de Alzheimer, dissolvendo temores e acolhendo sintomas da doença, dentro de interpretações próprias, atravessadas pela religião, cuidado, morte, alma e corpo.

Ainda que eu tivesse acesso às conversas sobre as idas às consultas médicas e realização de exames, não era meu interesse de pesquisa conferir diagnósticos- que, mesmo protocolados, permaneceriam fluidos devido à nevoa que cerca a doença (Feriani, 2017). Partindo de uma leitura de Mol (2002), esta etnografia compreende a doença de Alzheimer como uma ontologia múltipla e tecida na rotina das Irmãs, guiada pelas práticas da vida consagrada e pelos silêncios que caracterizam tanto a vida religiosa (como as orações) quanto a própria doença (como a confusão e ausência da narrativa verbal). Também é considerada como malha, a partir da teoria de Ingold (2015), por se conectar a muitas linhas possíveis, em que a doença de Alzheimer transborda do campo médico e mobiliza outras esferas, como família, grupos de apoio, blogs, fotografias, e questões, como noções de pessoa, doença, memória, realidade (Feriani, 2017) - no caso deste artigo, busco percorrer as relações da doença com a vida religiosa consagrada, o corpo e a etnografia.

O objetivo aqui é entender como a relação com o sagrado e a continuidade pós-morte influenciam a maneira das Irmãs compreenderem e lidarem com a doença de Alzheimer. A relação que as Irmãs estabelecem entre corpo e alma me fez aliar duas vertentes analíticas - a de Selfhood (Kontos, 2004) - tema tão abordado nos estudos sobre doença de Alzheimer - e o paradigma da corporeidade (Csordas, 2008; Merleau-Ponty, 1948), numa tentativa de apreender como esses corpos em processo demencial percebem o mundo e atravessam a experiência com a doença quando inseridos em um contexto religioso. Mostro como, para entrar nesse mundo tanto da vida consagrada quanto da doença -, foi preciso levar em conta outras estratégias de pesquisa, como as grafias e imagens. As fotografias, realizadas por mim, e os desenhos, feitos pelas Irmãs em oficinas que organizei, foram essenciais. Eles guardam uma infinidade de possibilidades de olhares e experiências do sensível, são vivos e ardem aos olhos (DIDIHUBERMAN, 2013), tornando possível, entre lacunas, borrões e composições não usuais em gavetas e mesas, fazer ver principalmente o que os silêncios, com os quais me deparei, não me deixavam encontrar no início. Neste sentido, o esforço é apresentar tanto as particularidades que a doença de Alzheimer assume em um contexto religioso da vida consagrada, quanto às particularidades de uma pesquisa etnográfica da doença.

\section{O contexto da Residência}

A Residência Carmen Sallés pertence às Irmãs católicas da Congregação Concepcionista. Esta teve origem em Burgos, na Espanha, em 1892, fundada pela Irmã Carmen Sallés, 
canonizada pela Igreja Católica em 2012. No Brasil, as Irmãs chegaram em 1912 e se estabeleceram em Machado, Minas Gerais. Desde então, a Congregação se espalhou para outros estados, com casas de formação, obras sociais, missões e colégios de educação formal (Valls Salip, 2014). O "carisma" da Congregação é a educação com o ensino de crianças e jovens. ${ }^{2}$ Contudo, ao longo das trajetórias das Irmãs, outras atividades estiveram presentes, como o auxílio às necessidades diárias das comunidades para quais os trabalhos sociais se voltavam, os trabalhos domésticos das casas em que vivem, com divisões de funções organizadas e a elas destinadas pelas superiores, com o cuidado voltado para os outros e para suas Irmãs.

Em 2004 a Residência foi criada para ser um lugar comum e final para todas as Irmãs Concepcionistas do Brasil que, por motivos de doença e dependência de cuidados, não consigam mais realizar os trabalhos da vida religiosa. Entre todos os agrupamentos de Irmãs no país, a Residência é a maior comunidade, com 13 Irmãs, entre dependentes e responsáveis pela supervisão da casa, de 77 a 94 anos, vivendo juntas. ${ }^{3}$ Mesmo nesse momento do curso da vida, as Irmãs, que realizaram votos perpétuos de pobreza, castidade e obediência, não retornam para suas famílias de origem, assim como são enterradas juntas na ocorrência da morte. Nesse espaço também estão presentes as cuidadoras remuneradas que atuam com os cuidados do corpo, além das profissionais que trabalham na limpeza e preparo dos alimentos. ${ }^{4}$

Ainda que com a avançada idade de todas, para as Irmãs não dependentes que ali vivem, as velhas eram as doentes e dependentes de cuidados. Explicavam que a velhice se fazia na impossibilidade de realizar os trabalhos da vida religiosa ou participar ativamente das atividades da Congregação. A dependência é própria da velhice com idades mais avançadas. Viver um número maior de anos, de acordo com Debert (2014) é enfrentar o declínio inevitável do corpo que passa a não responder às vontades individuais tornando-se ingovernável. Contudo, o que acontece entre as Irmãs é que só existe velhice quando há dependência de cuidados. Essa compreensão, no entanto, era questionada constantemente. $O$ lugar da velhice era reposicionado ou desconsiderado através da reivindicação da continuidade dos trabalhos e participação por algumas das Irmãs doentes residentes, ainda que de maneiras tidas pelas outras como inadequadas: leituras metódicas e repetidas dos mesmos trechos dos livros da liturgia e dobraduras incessantes de guardanapos colocados em gavetas. Irmã Petra, ao se colocar na

\footnotetext{
${ }^{2}$ Carisma pode ser entendido como a missão fundacional da Congregação (Fernandes, 2011).

${ }^{3}$ Atualmente no país são cerca de 60 Irmãs com uma média de idade entre 70 e 80 anos.

${ }^{4}$ Deixo a discussão etnográfica e teórica aprofundada sobre gênero, velhice e cuidado para outro projeto de pesquisa intitulado "Vida religiosa consagrada feminina e velhice dependente: uma etnografia dos arranjos diários em torno do cuidado" que será realizado no Mestrado em Antropologia Social pela mesma Universidade.
} 
posição de também cuidadora das Irmãs doentes, chamando-as todas por "Isabel”, não se via nem como velha nem como, ela própria, acometida pela doença de Alzheimer. Em vários momentos, reivindicava estar pronta para qualquer trabalho que a fosse atribuído.

A rotina da doença de Alzheimer na qual eu adentrei, ao viver com as Irmãs por cerca de 50 dias, tem a particularidade das descontinuidades, como afirma Engel (2020). Estas ocorriam em meio aos horários das refeições, horário da missa, das orações coletivas e individuais para as quais se via uma ou duas Irmãs em silêncio na capela ao final do corredor principal com um terço na mão, um livro e um guardanapo de papel. A Residência era um edifício de 3 andares. No térreo ficavam a cozinha e um salão onde eram feitas as confraternizações em datas religiosas festivas e velórios nas ocorrências de morte. No primeiro andar ficavam as principais áreas comuns: sala de comunidade, refeitório e a capela. No segundo, os quartos das Irmãs que também precisavam de cuidados durante a madrugada e no terceiro, os quartos das demais Irmãs e os vazios para as que chegarão.

Em todas as manhãs da semana eu participava do ritual da missa, mas não eram todas as Irmãs que eu encontrava na capela. O grupo das com DA era o que menos estava presente quando eu olhava ao redor nas cadeiras. Algumas Irmãs diziam que elas deveriam estar em todas as missas, já outras diziam que as doentes já não mantinham o silêncio - da oração e contemplação - necessário para o ritual ou consideravam cruel tirá-las da cama tão cedo. Irmã Matilde, com a doença, às vezes chegava à capela vestindo três camisas, uma sobre a outra. Também já adormeceu durante a celebração e as Irmãs passaram a dizer que ela não mais conseguia acompanhar o livro de orações. Na sala de comunidade, canais religiosos de televisão transmitiam as missas em outros horários do dia. Irmã Inés levava a "hóstia consagrada" para que o restante do grupo com DA comungassem durante o ritual da eucaristia. Em um dia, uma das cuidadoras começou a medir a pressão arterial das Irmãs no mesmo momento. Inés, então, sinalizou que aquele não poderia ser o momento das medições e que o horário deveria ser reorganizado em função do período de transmissão da missa. Depois de algum tempo, ela já não levava a "hóstia consagrada" - compreendida como a materialização do corpo de Cristo - para as Irmãs enfermas. Contou que algumas a mastigavam sem atenção ou então a cuspiam no chão. Entre a doença e o sagrado, era perceptível como a rotina, em meio às descontinuidades, encontrava seu ritmo.

\section{"Ainda que morta, viva em Deus": doença, corpo, vida e não-fim}

A vida religiosa consagrada originada com os votos perpétuos se faz no percurso da devoção, da entrega, do trabalho e esse percurso é aberto para a possibilidade de vida eterna.

\footnotetext{
${ }^{5} \mathrm{O}$ nome "Isabel" constantemente usada por Irmã Petra para se referir às Irmãs doentes de quem ela busca cuidar, também era o nome de uma das Irmãs com doença de Alzheimer, falecida pouco antes do início do campo. De acordo com as Irmãs, Isabel já vivia na Residência quando Irmã Petra foi transferida.
} 
Para Ingold (2015), a linha, ou a vida, que se move o tempo todo, pode vir a ser algo novo, ou seja, é feita na abertura e no devir. Essa noção de linha para a vida faz sentido para se pensar a trajetória da vida religiosa que se abre para o pós-morte. Uma linha sem fim, sendo, assim, assegurada justamente pelo percurso da mesma e as práticas que a compõem. A doença de Alzheimer, que passa a estar presente e entrelaçada nessa linha, é percebida de formas específicas. Isso se dá porque a trajetória religiosa dessas mulheres e as experiências envoltas nela são constitutivas de noções também específicas de corpo e pessoa (Martín, 2002).

As Irmãs seguem uma concepção de pessoa composta da dualidade entre corpo e alma, noção que Mauss (2003) já havia traçado como "pessoa cristã", que é, simultaneamente, remetida ao divino e ao humano. A alma, para as Irmãs, é o "sopro divino", a ligação de toda pessoa humana com o sagrado. E é a alma que permanecerá viva transcendendo a borda da morte. Contudo, ainda que dual, para elas é somente no conjunto entre as duas esferas que a vida no mundo é possível. Não existe corpo sem alma, mas existe alma sem corpo, no entanto, em um lugar fora do mundo. A doença de Alzheimer afeta unicamente o corpo, é nele que ela se encontra. A alma permanece protegida. Esta, ao longo da trajetória da vida consagrada ao sagrado, é cultivada através das obras. Assim, se a doença não é capaz de tirar os resultados dessa trajetória e também afetar a eternidade da alma, os possíveis temores em relação à DA, como a dissolução da pessoa ${ }^{6}$ e morte em vida, que aparecem em narrativas sobre processos demências (Feriani, 2017; Vianna, 2013) são praticamente dissolvidos e desconsiderados. ${ }^{7}$

é aquilo que eu disse, nem ganha e nem perde. Então a pessoa é consciente até chegar a esse estado, ela está tendo mérito, ela trabalha, ela reza, ela está tendo mérito, esse mérito aí não vai nunca ser perdido. E aí, é como um cofre que você guarda teu tesouro lá e você não mexe mais, o tesouro está lá. A nossa vida é essa. Agora, com Alzheimer, ela não vai perder o seu tesouro que foi a oração, foi a sua vida, feita por amor. É, a graça de Deus é o pagamento. Então, ali está, e no momento que ela esquece, ela não vai perder aquilo que ela já ganhou e o momento que, vamos suporo dia em que ela morrer, o Alzheimer não prejudicou a alma. A doença nunca se toca a alma. Toca o corpo, mas não toca a alma (Irmã Angelina, em conversa comigo).

\footnotetext{
${ }^{6}$ Feriani (2017) mostra como "dissolução do self" é uma expressão usada por médicos para se referir a um sintoma patológico, à perda da noção de realidade, ao não se reconhecer, por exemplo, ao se olhar no espelho. A autora problematiza tal expressão ao mostrar como ela se conecta a uma determinada noção de pessoa - e, portanto, de doença e realidade.

${ }^{7} \mathrm{Na}$ etnografia de Feriani (2017), quando a pesquisadora perguntou para uma filha que cuida da mãe com Alzheimer sobre possíveis alucinações, como ver algum parente que já faleceu, ela disse não ver dessa forma, pois, como são espíritas, acredita nessa possibilidade, não como sintoma patológico, mas como experiência mediúnica.
} 
Um dos contextos que apresenta que a DA e outras demências implicam na morte social, fragmentação, e perda da pessoa ou selfhood ${ }^{8}$, de acordo com Kontos (2004), é aquele feito a partir da noção dual de pessoa composta por dois opostos de corpo e mente. De acordo com uma cultura ocidental, a doença afetaria a mente, a selfhood, aquilo que é tido como o que nos constitui como pessoa. A pergunta que Kontos (2004) faz frente a isso é: deixa de ser pessoa quando se perde a memória? Através da defesa de fronteiras fluidas entre corpo e mente e do paradigma da corporeidade, ela responde que não.

O campo realizado por Kontos (2004) também envolveu a DA, cuidados e religião. Em uma instituição de longa permanência com predominância de residentes judeus, a autora observou como as pessoas com doença de Alzheimer continuavam expressando maneiras próprias de executar tarefas, realizar as orações, participar de ritos e mostrar sua espiritualidade em maneiras específicas e outras. Com a ausência de palavras, havia também gestos, olhares, outras formas de se comunicar e práticas carregadas de significados. Isso tudo porque a existência, as experiências e percepções, os aspectos sociais e memórias do corpo não se confinam no cérebro. São corporificadas e se manifestam de acordo com os contextos em que são no mundo.

A noção do colapso entre as esferas da mente e corpo compõe a proposta do paradigma da corporeidade de Csordas (2008). Este corpo, não dual, de acordo com o autor é figura metodológica, é o sujeito da cultura que experimenta o mundo, mas também a base de existência da cultura. Tudo passa pelo corpo.

O espaço da possibilidade da percepção, da experiência, é este estado pré-objetivo proposto por Merleau-Ponty (1948), em que, como analisa Csordas (2008), o autor recua do objeto pronto para como ele é percebido pelo corpo. Uma noção fenomenológica para o estar e perceber o mundo. Complementar a este espaço da possibilidade e da capacidade iminente do corpo de apreender e transmitir significados, temos o habitus de Bourdieu (2006). Para MerleauPonty (1948) a percepção e apreensão do mundo pelos doentes e "loucos" também ocorre, ainda que através da sua maneira. Para o autor, é um erro buscar compará-los à um suposto mundo coerente da pessoa sadia, quando na verdade essa coerência nem sequer existe. Por muito tempo, se não ainda hoje, encontraram nos doentes uma série de absurdos inexplicáveis, mecanismos cegos, caos vivo e ausência de sentido porque eram formas de existência distintas do que era entendido como normal (Merleau-Ponty, 1948).

A partir de toda essa abordagem, podemos pensar como o corpo foi a figura metodológica de acesso de toda a trajetória das Irmãs, e continua sendo. Se é a alma que se torna

\footnotetext{
${ }^{8}$ Escolhi manter a palavra para assegurar o sentido dela em Kontos (2004). A tradução para o português se aproxima de individualidade ou identidade.
} 
imortal, isso se dá através do corpo, das práticas, dos gestos, das orações, dos silêncios, dos comportamentos condizentes à vida religiosa consagrada. Foi para o corpo que eu depositei minha atenção em campo. A própria Residência foi organizada a fim de manter o "espírito de comunidade" específico, a espiritualidade corporificada. Tudo ali ocorre, ainda que existam práticas distintas que compõem a doença, através de um princípio unificador e gerador das práticas compartilhadas que buscam manter o percurso da vida consagrada vivo (Bourdieu, 2007).

Cabe aqui, no entanto, pensar nesta análise teórica da corporeidade, percepção e habitus que faço sabendo que Csordas (2008), Merleau-Ponty (1948) e Bourdieu (2006), cada um, no entanto, resguardam muitas particularidades. Trago a leitura de Citro, Lucio e Puglisi (2016) em que os autores propõe uma revisão da noção de habitus, compreendido como experiência corporal, explorando os vínculos possíveis com o ser no mundo da fenomenologia de MerleauPonty (1948). Ambos reconhecem o corpo como tendo um papel ativo, conhecedor das práticas e imerso no mundo. Contudo, este último, de acordo com os autores, não propõe uma metodologia de abordagem histórica e social deste ser no mundo, como Bourdieu (2006) o faz. Para este o habitus é um conjunto de práticas corporais vividas como mais naturais, sobre qual a ação consciente já não tem controle. No entanto, para Citro, Lucio e Puglisi (2016), se para Merleau-Ponty (1948) o mundo é sempre um horizonte por sempre indeterminado, em devir, Bourdieu (2006) compreende que esse potencial é circunscrito e circunscreve, em espaço e tempo, as práticas dos sujeitos. Sendo assim, aqui tomo os autores como complementares para a minha análise.

Existe um habitus da vida religiosa, apreendido pelas Irmãs ao longo dessa trajetória atravessada pela religião, pelo gênero e pela vida consagrada. O tipo de roupa, o formato, as coisas que carrega junto ao corpo, a forma de cuidar, de falar e se posicionar frente ao sagrado, as práticas atravessadas pelos votos de pobreza, obediência e castidade que compõem a rotina religiosa presente mesmo no contexto da Residência. Contudo, em meio à rotina religiosa e o habitus, ainda que elementos dele sejam encontrados o tempo todo, a doença de Alzheimer traz outras demandas possíveis em um horizonte indeterminado de experiências (Merleau-Ponty, 1948), descontinuidades na rotina e possibilidades em devir que espantam.

Um dia, uma das Irmãs com DA começou a se despir no momento da refeição. Algumas ficaram incomodadas, outras riam, uma tentou tampar seu corpo rapidamente e outras diziam "deixa ela!". A resposta da Irmã que se despia para as reações todas foi a de que, desde que Deus criou o mundo, ninguém veio para cá vestindo roupas. E todas concordaram, ainda que fosse possível vê-las ajeitando suas roupas na poltrona ou separando qual vestiriam na missa. Ou seja, há um habitus da vida religiosa que é reforçado o tempo todo, mas também existem as negociações e o acolher destes movimentos outros trazidos pela doença de Alzheimer. 
Eu tive acesso a um livro das Irmãs com breves descrições sobre a vida de todas as que já haviam morrido na Congregação desde a fundação. Realizei um levantamento e notei que, desde o início do século XX até os primeiros anos da década de 90, não havia qualquer menção ao nome "doença de Alzheimer". ${ }^{9}$ Contudo, haviam descrições de sintomas semelhantes, como "viveu em inconsciência", "sofreu alterações em suas faculdades mentais". Foi interessante perceber como se levantavam, mesmo no período de "inconsciência" ou "alteração"10, características e comportamentos da vida religiosa percebidos apesar da doença. Em nenhum momento a morte era apresentada como um fato negativo. Pelo contrário, carregava uma capacidade de refazer a vida, transcender a enfermidade através da recuperação divina e da promessa de uma vida espiritual eterna. "Já em Deus, tudo foi recuperado e aumentado", constava sobre a morte de uma delas.

Ao mesmo tempo, no entanto, em que as Irmãs concordam com essa relação da doença e corpo, alma e eternidade, existem também práticas diversas, que não necessariamente são controversas, mas estabelecem relações distintas entre si (Souza, 2015). Assim, mesmo acreditando na eternidade da alma e que a doença somente atinge o corpo, uma das Irmãs rezava todos os dias para não ter Alzheimer, outra fazia garrafada de alecrim e mel para a memória e buscava, em livros, o que mais poderia fazer para se proteger.

De acordo com Mol (2002) a ontologia múltipla de uma doença em questão é feita através dos corpos, dos saberes médicos, dos cuidados, dos sintomas e dores, das tecnologias envolvidas nos tratamentos e diagnóstico, das formas como o doente descreve sua experiência. Tudo isso entrelaçado, em tensão. Segundo a autora, as ciências sociais se dedicaram, por muito tempo, a pensar ilness, a esfera da experiência da doença, deixando disease, a esfera biológica e do corpo, para os saberes biomédicos. No entanto, ela propõe uma etnografia do corpo. A sua atenção é para como as realidades da doença e corpo são atuadas de distintas formas em distintos contextos e constituídos na prática. Em sua pesquisa sobre a aterosclerose em um hospital na Holanda, buscou entender a doença em suas práticas, materialidades e associação de elementos heterogêneos e como, através dessas diversas possibilidades de atuação, a doença, ela própria, se multiplica (Souza, 2015).

A importância de se pensar a doença de Alzheimer através da perspectiva ontológica se dá pela noção de que a doença pode ser feita de outras maneiras, se afastando assim de representações da mesma e enfatizando as práticas em que a doença é feita diariamente na Residência. Como explica Souza (2015), pensando a partir de Mol (2002), existem muitas

\footnotetext{
${ }^{9}$ Como apresenta Leibing (1999), a doença de Alzheimer como categoria médica se popularizou no Brasil somente no início dos anos 90. Outros nomes, contudo, existiam. Em entrevista com as Irmãs ou conversas informais, não é difícil ouvi-las dizendo que "antes não existia essa doença". Quando as Irmãs se referem às do passado citando comportamentos parecidos, falam de "loucura" ou "traumas de antes de tornar-se Irmã".

${ }^{10}$ As Irmãs também posicionam o cognitivo, mente, na esfera do orgânico e do corpo em oposição com a alma.
} 
versões de uma doença, que coexistem entre si, e também técnicas através das quais ela se faz reconhecível, audível. Híbridos entre práticas humanas e, no caso da aterosclerose, bisturis, microscópios, artigos publicados e outros. Aqui na Residência, a doença se faz perceptível através dos escritos das Irmãs, conversas, silêncios, afetos, olhares, orações, esquecimentos, mas também dos terços, novelos de lã, agulhas, gavetas, orações, imagens de santas, remédios, panos embrulhados, guardanapos de papel que vão compondo um mundo na intersecção entre vida religiosa consagrada e a doença de Alzheimer

\section{Corpos, afetos e guardanapos de papel}

Ao encontrar com a Irmã Anastásia no elevador da Residência, a caminho do seu quarto, perguntei se podia acompanhá-la e ela respondeu que sim misturando palavras em português e espanhol. Caminhava com auxílio de uma bengala segurando-a com uma das mãos e, na outra, carregava um cobertor marrom-claro, bem dobrado, que ela levava para a sala de comunidade, todos os dias pela manhã, e voltava com ele para seu quarto durante ou no fim do dia. Nesse cobertor, envolvia alguns papeis, mensagens religiosas, cartas e cartões, inteiros ou recortados, lenços de papel e duas revistas mensais de orações diárias que não necessariamente eram daquele mês. Em seu quarto, poucos móveis e, sobre eles, imagens religiosas de santas e da madre fundadora Santa Carmen Sallés. Ela me mostrava cada parte de seu quarto, em tom receptivo como alguém que recebe uma visita em casa. Indo na frente, me apresentava seu banheiro, os objetos sobre a pia, suas toalhas com seu nome escrito, detalhando como havia arrumado cada coisa em seu lugar. Indo para as gavetas, ela parecia ir descobrindo o que havia ali junto comigo, "vamos ver", "o que tem aqui?". Papeis, embrulho de presente, uma caneta sem tampa, um lápis, elásticos de jornal, uma estrela dourada da decoração de natal, algumas balas. Abriu outra gaveta e inúmeros pedaços de papel higiênicos e guardanapos começaram a surgir. Dobrados com perfeição, eles se transformaram em quadrados equilibrados uns sobre os outros. Quando perguntei se ela estava guardando tudo aquilo, logo respondeu que "não, se alguém precisar, eu dou!”

Quando eu estava para sair do quarto, perguntei se fazia muito tempo que ela morava ali na Residência. A resposta foi rápida: "pois eu vim para cá junto com você". Nós duas seguimos com ela olhando se nos quartos ao lado já havia alguém "morando", como se referiu às demais Irmãs, para que eu também pudesse morar.

Pode-se perceber, com o quarto e as narrativas de Irmã Anastásia, elementos da moral religiosa das Irmãs, que coincidem com seus votos: a doação, o trabalho, a pobreza, que constantemente estão presentes nas orações, falas e corpos de todas elas. Os poucos objetos que, ainda assim, doaria se fosse necessário, um pedaço de guardanapo que ela repartiu comigo, a leitura repetitiva e incansável da bíblia estão de acordo com a vida religiosa que escolheu seguir. Se guardar papéis e guardanapos e ler repetidas vezes as orações, todos os dias, poderiam soar 
como comportamentos estranhos ou sintomáticos da doença, aqui eles também indicam a dedicação e o compromisso com a espiritualidade. A preocupação em arrumar um quarto para eu morar indica como minha presença era vista e transformada ao longo da pesquisa, o que me fez, de alguma maneira, experimentar certas confusões, quase adentrar delírios, ser convidada a experimentar o contexto delas de forma engajada (Ingold, 2015). Pesquisadora, aluna do colégio onde deram aula, cuidadora e, até mesmo, uma das Irmãs doentes que passaram a morar na Residência, tal como Irmã Anastásia me via. Essas várias posições que me foram atribuídas me deslocaram por diferentes atividades - ora eu era pesquisadora, ora eu era uma moradora e, como tal, também tinha que assumir alguns deveres. Irmã Aurora, acompanhando-a em uma ida até cozinha, me perguntou "você já sabe alguma coisa sobre a nossa vida religiosa, então?" e, logo em seguida, comunicou sobre mim à uma das cuidadoras, entusiasmada: "ela vai ser freira!".

Aprendi orações, trabalhei com a ajuda em servir e retirar os pratos da mesa, ajudei cuidadoras e Irmãs em afazeres no geral. Ajudava com pequenas atividades do corpo, da higiene, da alimentação, vivendo uma etnografia que passou, assim, pelo meu próprio corpo, como aquele que se movimenta, apreende e intermedia meu acesso com o mundo das Irmãs, como uma figura metodológica de percepção (Merleau-Ponty, 1948; Csordas, 2008). Atenta às suas atividades, passei a realizar o cuidado me aproximando dos modos como elas o faziam. Estar lá me pedia uma certa postura do corpo, das roupas - que ora eram aprovadas ora reprovadas pelos olhares das Irmãs - e, inclusive, a ausência das minhas palavras - cheguei a ser repreendida ao conversar com uma das Irmãs na capela, local em que o silêncio da contemplação deveria reinar. Era preciso um corpo em que se pudesse engajar (Ingold, 2015) e, com isso, deixar-me levar pelo campo, permitir-me ser afetada.

A dimensão do afeto no trabalho de campo é discutida por Favret-Saada (2009). A autora diz que considerar e permitir a modalidade de afetar-se foi o que tornou possível adentrar o mundo da feitiçaria no Bocage, assim como repensar toda a etnografia. Para ela, existe uma literatura antropológica da feitiçaria que tratou a palavra nativa como erro, fantasia e/ou crença ao deixar escorrer a verdade sobre o que era observável, verificável aos olhos do etnógrafo, como, por exemplo, desqualificar a invocação da feitiçaria, difícil de ser observada, para explicar uma doença. Essa observação distanciada, que, ainda que possível, seria rasa, não aconteceria naquele contexto, pois o campo exigia outra relação para se fazer entender. Os nativos queriam que ela experimentasse com seu próprio corpo e sensações os efeitos reais que compõem a rede particular de comunicação da feitiçaria. Ou seja, permitir-se ser afetada.

A autora mostra como passou a compreender a importância epistemológica e metodológica das comunicações involuntárias e não intencionais, ao contrário de tomar uma posição permanente de uma comunicação etnográfica ordinária em que toda comunicação é verbal, intencional e voluntária, e, de acordo com ela, incapaz de acessar e fornecer o conhecimento daquilo que, na experiência humana, não ocorre de maneira intencional (Favret- 
Saada, 2009). Se isso se faz importante para qualquer etnografia, parece ser ainda mais quando se trata de adentrar vidas de pessoas acometidas pela doença de Alzheimer, em que a confusão, desorientação, o não reconhecimento de si e a perda da linguagem verbal ficam comprometidos.

Quando Favret-Saada (2009) fala em afetar-se não significa se identificar com o campo, mas aceitar o risco de ver seu projeto de conhecimento se desfazer ou precisar ser repensado. E, com isso, ter que repensar, além do lugar do seu corpo em campo, as técnicas metodológicas. Até porque permitir ser afetada é também estar atento aos movimentos e especificidades do campo.

Neste sentido, ao discutir a participação corporal da(o) etnógrafo(a) a partir de seu campo com grupos de meditação na Argentina, Puglisi (2019) propõe uma "etnografiapresente". Também para o autor, toda cultura passa pelo corpo, é encarnada (Merleau-Ponty, 1948; Csordas, 2008) e assim, todo grupo habita um suelo corporal ${ }^{11}$ fonte de suas práticas e discursos - silêncios - e que exige, para além da observação tradicional, que o habitemos corporalmente - ou morar, como disse Irmã Anastásia. Isto nos pede o apreender das práticas em que, no entanto, fazer como os outros fazem não significa experimentar exatamente o que experimentam. E sim, abrir a experiência etnográfica à uma outra dimensão no horizonte de sentidos articulados pelos sujeitos.

\section{E os não dizíveis: como adentrar?}

Em meio a esse emaranhado de coisas, afetos e práticas, o silêncio se mostrou um componente importante na configuração tanto da doença quanto da vida consagrada. Não só o silêncio da confusão, da perda da narrativa verbal, mas também o silêncio das orações e contemplação. Deparei-me com esses dois tipos de silêncio, que as vezes se confundiam e se sobrepunham, da mesma forma que eu, atenta, aprendi a me silenciar. Em uma tarde acompanhava Irmã Aurora até a capela, tentei começar uma conversa, mas ela logo me sinalizou carinhosamente "shiu", "vamos rezar bonitinho!". Ainda que eu tenha realizado extensas entrevistas em profundidade, mantido um cuidadoso caderno de campo, outras técnicas metodológicas se faziam necessárias. Técnicas que pudessem romper a camada dos não-ditos e se fazerem presentes quando as palavras não podiam.

Essa foi uma questão para Rocha (2012), pois em seu campo o autor passou pela necessidade de pensar em outras estratégias antropológicas, para além das entrevistas e observação participante, para conseguir se comunicar com os silêncios das beatas. Essas mulheres condensavam em suas condutas religiosas e em suas corporeidades signos importantes para compreendê-las e acessar o imaginário estético sobre o qual elas se recusavam a falar quando questionadas pelo pesquisador. A fim de transcender os não-ditos, o autor buscou a

\footnotetext{
${ }^{11} \mathrm{O}$ "suelo corporal" aqui se apresenta como uma outra possibilidade teórica ao habitus de Bourdieu (2006).
} 
produção artística de artesãos locais que faziam as esculturas das beatas e,com isso, aspectos que haviam sido interditados nas falas surgiam nas explicações dos artistas e na própria forma das beatas esculpidas. $\mathrm{O}$ autor percebeu, assim, que os corpos retratados eram como porta-voz de mensagens religiosas que, na verdade, não moravam nas palavras. Como Rocha (2012), que se viu em quase uma "trincheira etnográfica" diante das dificuldades iniciais de adentrar a ontologia religiosa das beatas, vi-me assim em alguns momentos na Residência. A necessidade de ver e fazer ver me fez recorrer às fotografias feitas por mim, e aos desenhos produzidos por algumas delas. E, com isso, percorri os quartos, as gavetas, as coisas, os retratos, as rezas e os silêncios.

As imagens - fotografadas e desenhadas - são consideradas, aqui, como uma potência para trazer à tona outras narrativas possíveis, os não-ditos, as nuances não anotadas no caderno de campo, mas presentes nas dobras das fotografias, dos gestos, dos desenhos das Irmãs. As imagens me possibilitaram ver a doença sendo feita de outras maneiras pois elas "torcem as palavras, reinventam a linguagem, criam novos contextos de enunciação, tensionam discursos oficiais, oferecem outros mundos e outras formas de reconhecimento" (Feriani, 2017: 293).

Em Hummel (2017), a autora trabalhou com a fotografia em uma dessas instituições criadas por congregações e o objetivo era pensar, através de imagens, o envelhecimento das Irmãs. No entanto, ela se deparou, ao procurar fotografar a rotina, com objetos e atividades que não eram considerados "fotografáveis" pelas Irmãs e cuidadoras. Entravam nessa coleção de coisas desde curativos, o momento em que ainda não se estava vestida com o hábito e o escudo, até limpezas dos quartos ainda sendo feitas. Se a pesquisadora se propôs acessar esse mundo através da imagem foi pensando em sua potência de aproximação das dimensões do sensível. Da mesma forma, essas dimensões são importantes aqui.

Fotografei o cotidiano ao longo da pesquisa, assim como organizei oficinas de pintura, desenho e escrita de cartas junto à algumas das Irmãs com doença de Alzheimer. Tais imagens compõem possibilidades visuais para pensar na experiência da DA na Residência. Samain (2012) destaca o reconhecer desses lugares - outros da expressividade, narrativa, comunicação através da polissemia das imagens e do sensorial humano. As imagens nos oferecem elementos para pensar, pois elas também são "formas que pensam" com tempos difusos, vivos e entrelaçados, causando questões, fornecendo-nos "ora um pedaço do real para roer, ora uma faísca de imaginário para sonhar" (Samain, 2012: 22).

A potência das imagens em relação ao sensível busca ser prolongada para este artigo. Estão aqui, por entre a escrita, como experiência sensível (NOVAES, 2015) para quem lê, olha e percebe. Os olhos poderão inquietar-se, romper a superfície, ver o que as imagens guardam de mais profundo (Samain, 2012). Dessa forma, além das imagens serem uma possibilidade metodológica de adentrar os silêncios e criar questões, elas também mostram algo da experiência e percepção do mundo da doença, da rotina, do cuidado, das Irmãs, das composições de coisas. O objetivo, aqui, não é enquadrar a experiência, os desenhos e fotografias em conclusões e, sim, 
permitir a abertura de pensamentos, movimentos e afetos. Tal como a etnografia, os desenhos e fotografias não escapam de uma peregrinação incansável e um destino sem fim de pensamentos e olhares possíveis (Samain, 2014).

Não necessariamente busquei, com os desenhos e pinturas nas oficinas, interpretar, desvendar significados, encerrar as experiências em conclusões. O interesse maior foi acompanhar os desenhos sendo feitos, o movimento do fazer, as reações que surgiam e os espaços de diálogo que se abriam. Enquanto Irmã Aurora circulava com a tinta vermelha em uma folha de ilustração, com alguns pássaros coloridos por outra Irmã, ela me perguntava sobre minha família, meus estudos e constantemente me convidava a perguntar mais "o que mais?", "o que mais quer saber?". O movimento repetitivo e circular - e que deu origem a um borrão vermelho, rasgando a folha - também foi um movimento de se abrir à conversa, às minhas perguntas, ao interesse em nos conhecer.

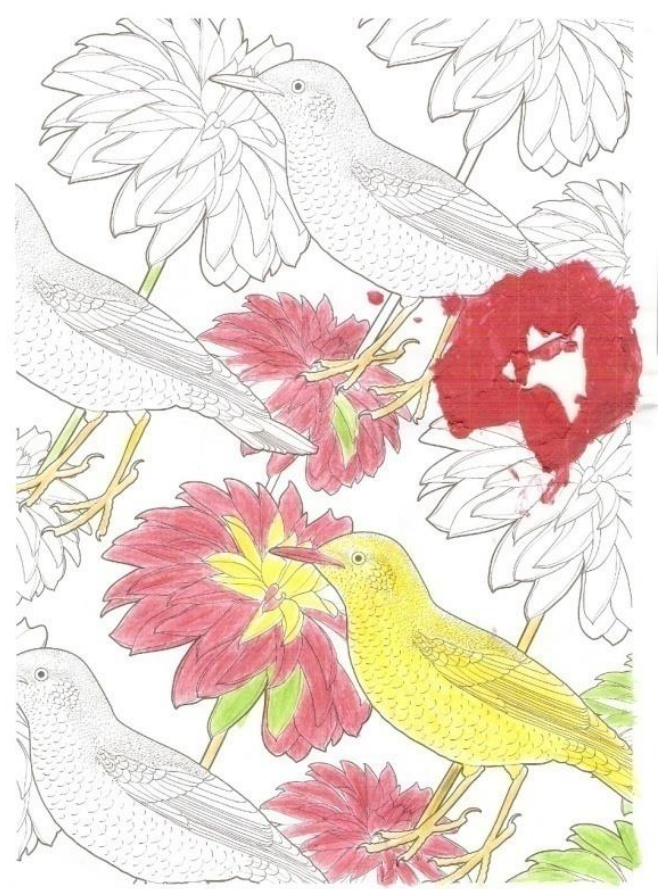

Figura 1: O borrão vermelho. Desenho de Irmã Aurora (2017).

Ainda que não fosse o objetivo desvendar significados, os desenhos causavam reações e criavam pensamentos não só para mim, mas para as outras Irmãs que pediam para ver, perguntavam o que era. Gravuras coloridas, pinturas e desenhos livres sobre o papel, borrões, fios soltos traçados, palavras escritas inteiras ou pela metade. Um dia, Irmã Júlia começou a escrever no papel palavras umas sobre as outras. Escolhendo colocá-las dessa forma, quase dando nós nas linhas que se embaraçavam a cada letra que ela escrevia, foi se compondo uma imagem. 
Como multifilamentos de uma trajetória de vida e fazeres da doença, havia nomes de irmãs, familiares, mortos e vivos, inteiros ou fragmentos.

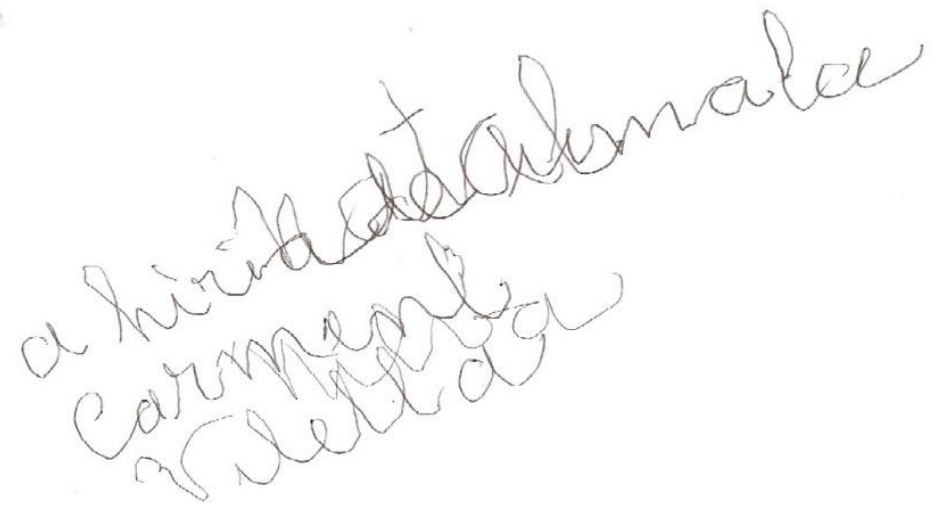

Figura 2: Multifilamentos de uma história de vida. Desenho de Irmã Júlia (2017).

Os desenhos também são um tema para Ingold (2015), como um trabalho simultâneo de se aproximar, quase habitar, os movimentos pelos quais as pessoas, coisas, narrativas passam pela experiência da observação e nas linhas traçadas no papel. Ao olhar para os desenhos das Irmãs, os fragmentos, os borrões, as pinceladas, os círculos, os rasgos, as linhas que fogem das bordas não poderiam ser descrições de suas próprias trajetórias? Não estão, também eles, contando algo de suas experiências?

Quando mostrei para Irmã Petra a foto dela que tinha acabado de fazer, ela me perguntou se era a minha avó. Quando eu disse ser ela, respondeu, rindo: "Eu? Que velha!", "eu nunca tinha me visto assim! Quando tiraram isso?". Espelho, rosto, imagem - mesmo em uma fotografia - "são tanto coisas quanto metáforas para revelar o devir-outro da doença através de uma galeria fantasmagórica de cenas, relatos, gestos, sintomas" (Feriani, 2017: 157). Em Villela (2015), a autora trabalha as noções de pessoa e corpo articuladas com imagem em uma sociedade indígena. A fotografia, tirada por pesquisadores nessa sociedade, agia como um agente patológico, pois, no momento da foto, um princípio vital da pessoa, que só poderia ser manipulado pelos xamãs e divindades, era retirado. Assim, a imagem se torna também parte constitutiva do sujeito, pois carrega seu princípio vital, seu "eu" podendo, inclusive, adoecê-lo. Para Irmã Petra, a fotografia agiu como um agente capaz de torná-la outra, uma pessoa tão mais velha a ponto de poder ser minha avó.

Em uma visita ao quarto da Irmã Matilde, ela disse para eu fotografá-la junto a sua família: retratos e imagens de José, Maria - pais de Jesus, para os cristãos -, Jesus, a Madre fundadora. A Irmã costumava dizer que seus pais, daqueles antigos retratos, estavam vivos, que precisava ligar para eles para mandar notícias, perguntar como estão. As outras Irmãs me disseram que isso não era possível, pois ela já tem 86 anos. No entanto, não diziam que eles estariam mortos. As imagens dos pais vivem em um espaço de lacunas e sobreposições de 
tempos, olhares, percepções, delírios. E, para esse contexto religioso, também vivem em um lugar - outro que mantém a continuidade da vida - "ainda que morto, vivo em Deus", como dizem as Irmãs. A imagem, como o delírio, "faz aparecer o que desapareceu, torna presente o ausente" (Feriani, 2017: 285).

Irmã Petra guardava uma sacola em uma das portas do armário da sala de comunidade. De lá, constantemente retirava uma peça que está tricotando, suas agulhas e novelos. Em um dia, começou a "cavar" mais fundo e adentrar a sacola. Ia puxando novelos soltos, um cachecol, encontrando cartões, para os quais ela, surpresa, perguntava em voz alta "quem me deu isso?". Uma bula de remédio pela metade, outra com linhas enroladas. As outras Irmãs continuavam suas coisas, seus crochês, suas leituras, assistiam a televisão, mas eu a observava sentada em uma das poltronas, enquanto ela ia descobrindo seus próprios guardados, conhecendo-os. Ela, então, encontrou um porta-retrato que havia ganhado da madre geral em sua última visita ao Brasil. $\mathrm{Na}$ foto, uma antiga estátua da madre fundadora junto a crianças. Ela olhou sorridente para aquele retrato e me chamou dizendo "estes são meus sobrinhos!".

Mais tarde, perguntei se podia fotografar suas coisas na sacola e, outra vez, esses objetos começaram a ser descobertos. Ao colocá-los em uma superfície para uma fotografia, pude notar que também havia, entre aquele quebra-cabeça, duas das minhas canetas, lápis e um envelope que eu talvez tenha esquecido próximo a sua poltrona. A imagem composta, como as diferentes pessoas que eu me tornei ao longo dos dias, era eu, enquanto pesquisadora, ou residente, ou Irmã, adentrando àquele mundo, o habitando (PUGLISI, 2019), me enrolando nos fios dos novelos de suas sacolas, histórias, vida consagrada e doença.

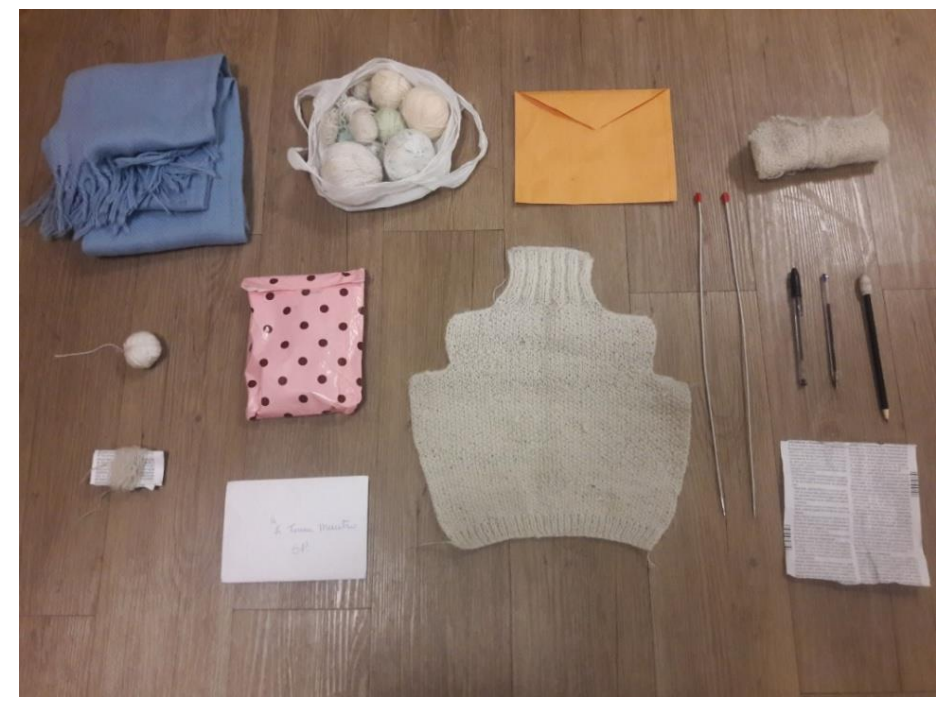

Figura 3. Quebra - cabeça de afeto e guardados descobertos. Fonte: A Autora (2017). 

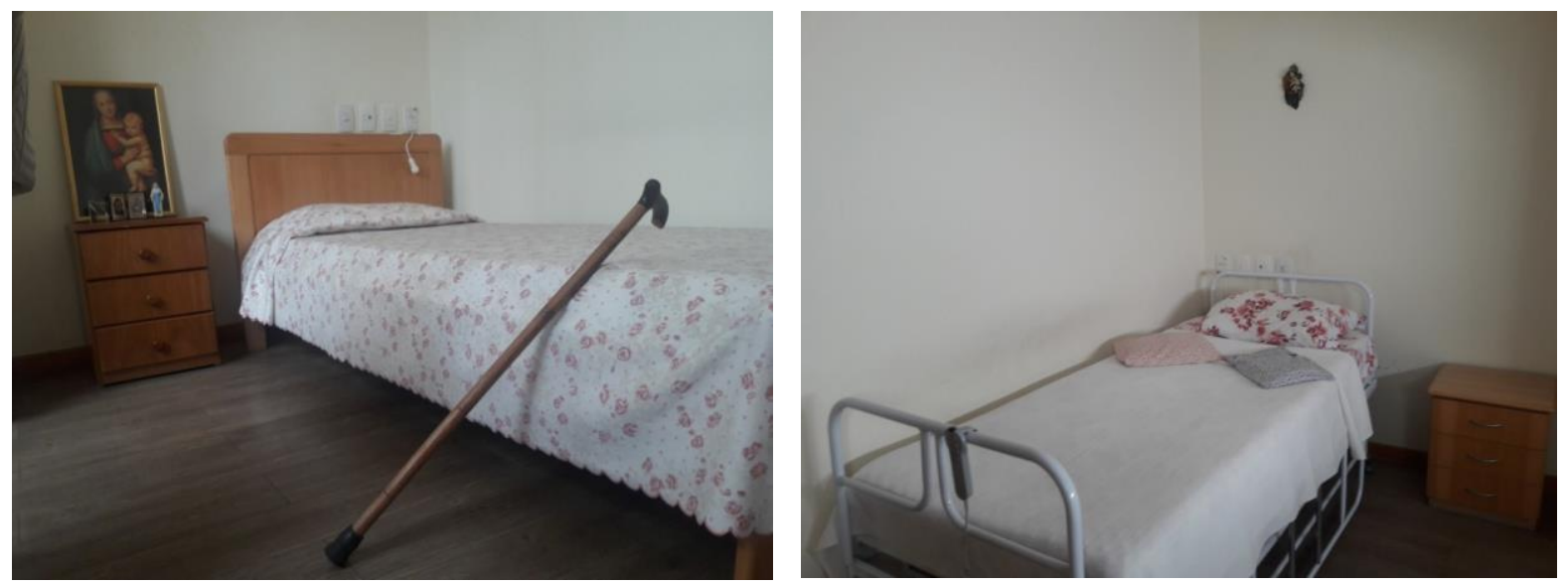

Figuras 5 e 6. entre a doença e o sagrado, a rotina encontra seu ritmo. Fonte: A Autora (2017 e 2019, respectivamente).
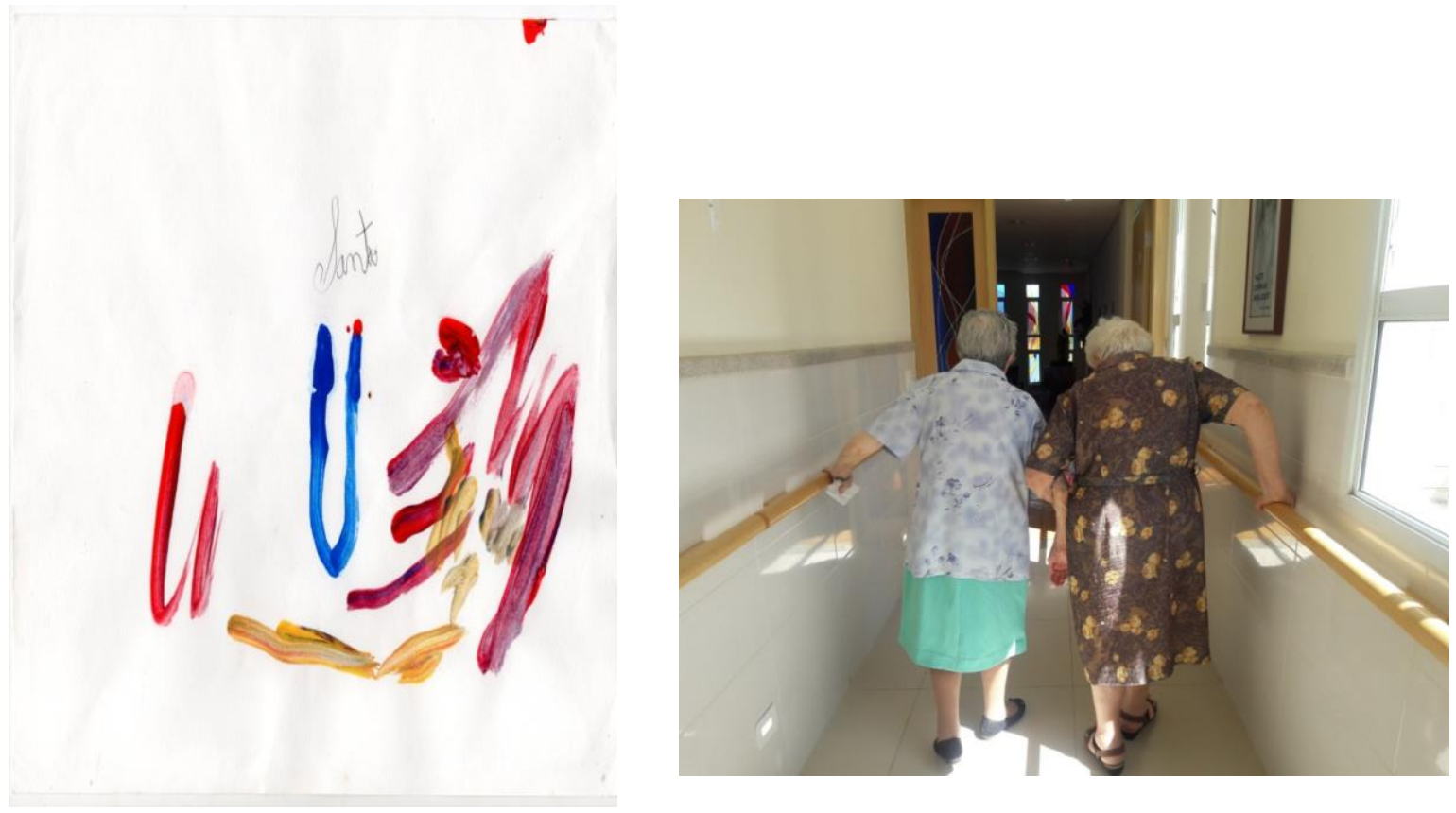

Figuras 7 e 8. "Santa" e as linhas (à esquerda) e a continuidade do cuidado (à direita). Fonte: desenho de Irmã Julía (2019), foto da Autora (2019).

Observar as imagens também pede atenção e espanto. Como defende Didi-Huberman (2013), convém olhar como um arqueólogo que insiste em não concluir que não exista mais nada para ver. Através desse olhar é que os tempos anacrônicos, os elementos do contexto sobrepostos nos olham de volta. Será possível, assim, encontrar as articulações, mas também os 
conflitos que se cruzam. Nas composições que seguem estão presentes as Irmãs, uma rotina atravessada pela doença de Alzheimer, tempos híbridos, delírios, afetos, cuidado, conflitos, olhares meus e delas, coisas que não necessariamente serão solidárias entre si na produção de um sentido comum ou lineares (Entler, 2014). Nas lacunas entre uma fotografia e outra, um desenho e outro ou nas combinações e aproximações delas surgem as narrativas que os silêncios não me permitiam trazer nesta escrita. A imagem não é um simples recorte do mundo das coisas visíveis; ela é um traço, um rastro visual do tempo que quis tocar, mas também de outros tempos anacrônicos e heterogêneos que se sobrepõem (Didi-Huberman, 2012). Como o autor diz, a imagem é uma mescla de cinzas com braseiros mais ou menos ardentes.
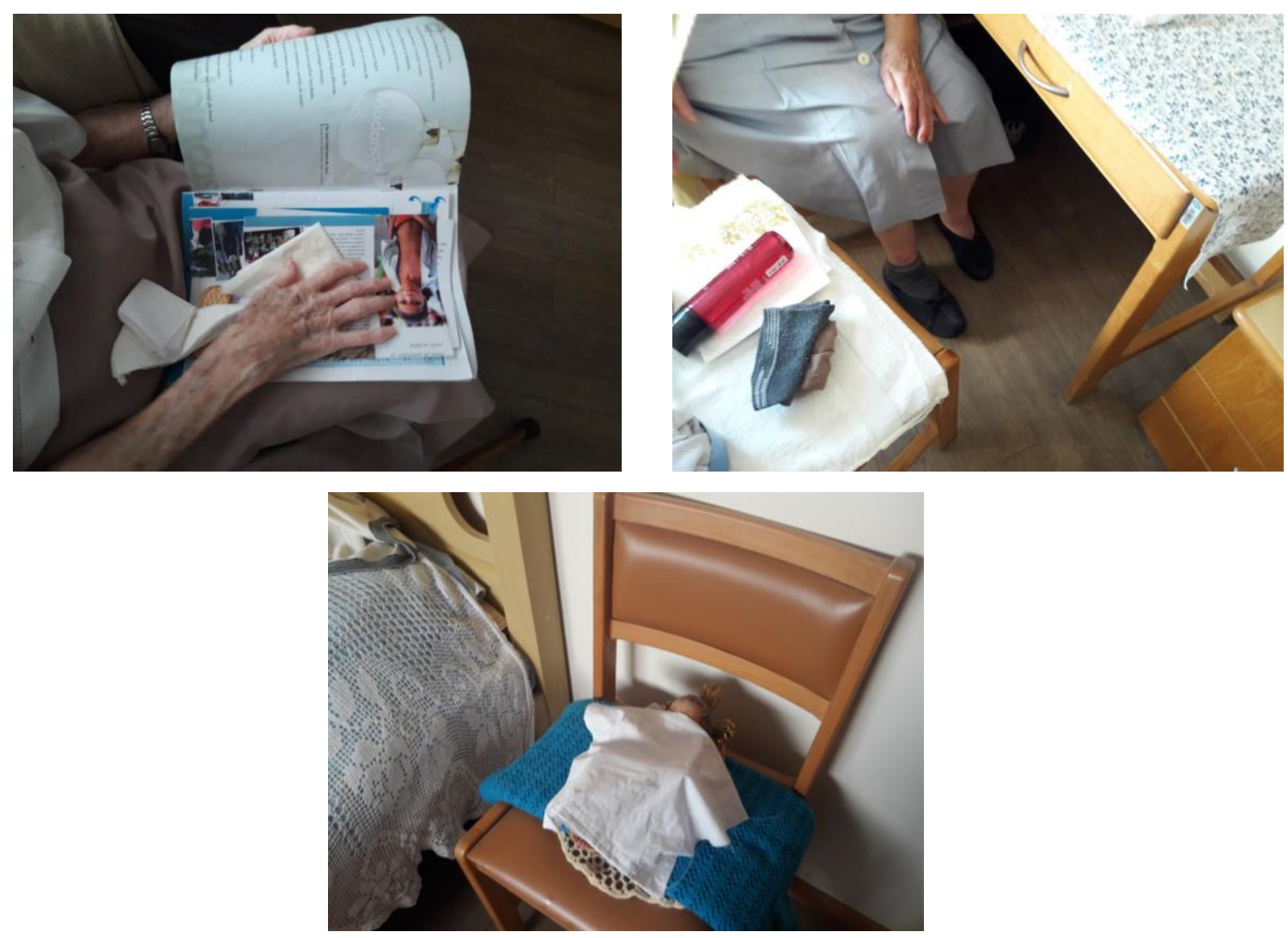

Figuras 9, 10 e 11. sobreposições de guardanapos, tempos, delírios e o sagrado. Fonte: A Autora, as duas primeiras imagens foram produzidas em 2017 e a terceira em 2019. 

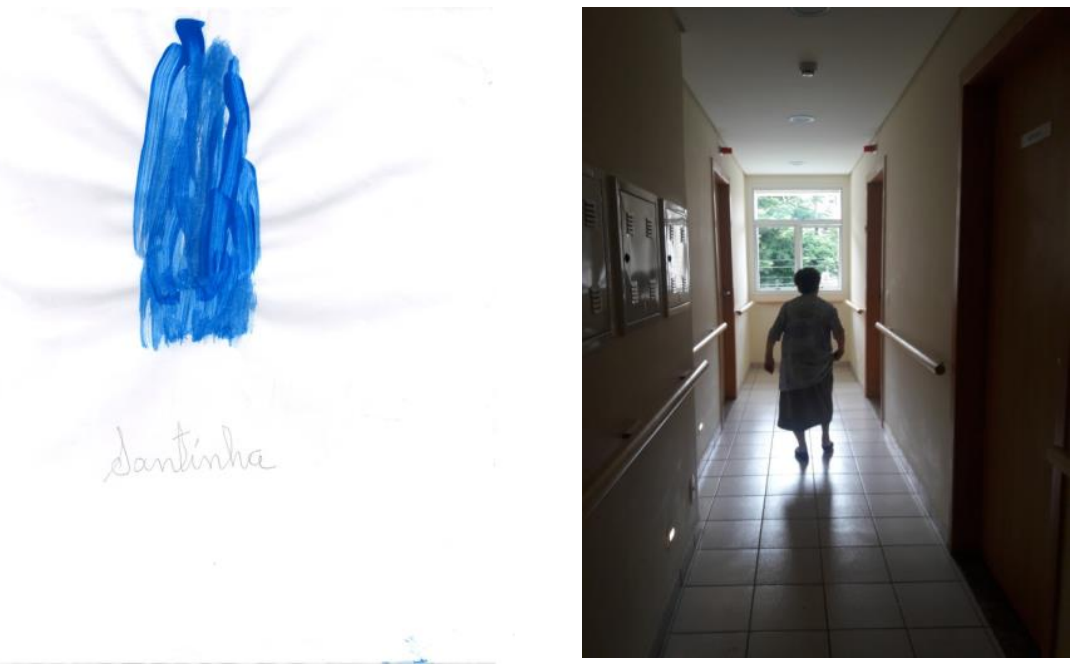

Figuras 12 e 13. Santinha (à esquerda) e os corredores e o silêncio (à direita). Fonte: Desenho de Irmã Júlia (2018) e fotografia da autora (2018).

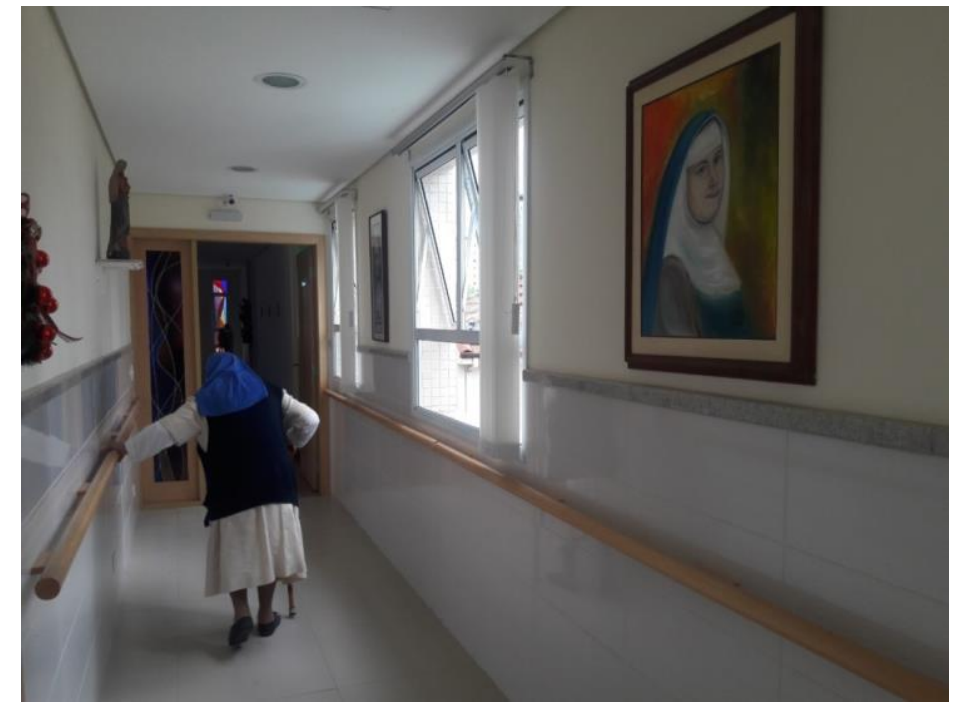

Figura 14. Santa Carmem Sallés e o tempo. Fonte: A Autora (2018).

\section{"O que esses olhos me dizem?": uma conclusão}

Retornei do campo com um material etnográfico extenso. E com dezenas de guardanapos de papel, que eu recebia das Irmãs ou encontrava pela Residência. Como uma metáfora da multiplicidade de coisas, afetos, silêncios e práticas diversas e espantosas que compõem e fazem essa ontologia. Como os fios que vão se entrelaçando, em tensão, mas não controversos (Mol, 2002; Souza, 2015), que através da rotina de horários e descontinuidades, de compromissos e espantos, tecem a malha que busquei acessar (Ingold, 2015). Os guardanapos 
apareciam na sala da comunidade, nas cadeiras da capela, nos cuidados, na hora da refeição, nos bolsos e gavetas, entre as páginas dos livros de oração, esquecidos e descobertos aos montes com espanto e no ofício delirante de dobrá-los.

Comecei este artigo com a carta de despedida que escrevi para a Irmã Anastásia. A morte dela é uma borda do papel a se atravessar com a linha da vida (Ingold, 2015). Uma linha que segue na imortalidade do espírito e, assim,"não precisa segurar a vida", como diziam. A DA, para qual a Irmã recebeu o possível diagnóstico, não foi capaz de afetar a esfera da alma cultivada ao longo da trajetória através da doação ao trabalho, do cuidado e dos votos perpétuos - um trabalho feito incansavelmente pelo corpo -. Articulando aqui a noção de ontologia múltipla de Mol (2002) e de uma etnografia do corpo que ela propõe, me atentei para como doença e corpo e são atuados e vividos, nas práticas e silêncios.

Irmã Anastásia, ao me dizer que ainda me faltava morar, me fez entender que para acessar esse mundo eu precisaria permitir-me afetar (Favret-Saada, 2009), habitar corporalmente e apreender as práticas da rotina junto às Irmãs (Puglisi, 2019). Não só por eu ser uma pesquisadora que propôs uma etnografia de vivência intensa e participativa entre elas, entre o habitus da vida consagrada ou o suelo corporal da Residência - nas roupas, nos horários, na postura do corpo, no cuidado e nas tarefas da casa -, mas também pelo como minha presença era percebida e transformada, o tempo todo. Para Anástasia, Aurora e Petra, uma Irmã como elas. Me convidando à acessar delírios, a conhecer uma dimensão outra de sentidos, a suspender meu próprio mundo, assim como Feriani (2017) para adentrar o mundo das Irmãs. Uma "etnografia assombrada" que me levou, contudo, como narro na carta, à um "assombro reverente" (Sacks, 1997).

Ao me mostrar a sua gaveta repleta de coisas heterogêneas, Anastásia me convidava a ver as materialidades que também compõem a ontologia múltipla e a malha da doença na Residência (Mol, 2002; Ingold, 2015). Guardanapos, um relógio parado, fotografias antigas, trechos de orações escritas em papeis dobrados, balas em embrulhos brilhantes. Assim como na sacola de Irmã Petra, com novelos, agulhas, imagens de santas e meus lápis que passaram a fazer parte dessa composição. Essas coisas todas, ligadas à vida consagrada e a DA, articulam olhares e experiências do sensível, que espantam aos olhos e ardem (Didi-Huberman, 2013).

Ao me convidar ao silêncio e me perguntar o que os meus olhos conseguiam ver nestas condições, o que tinham para dizer, Irmã Autora também me convidava à atenção metodológico que atravessou toda essa etnografia. Como Puglisi (2019) que ao passar muitas horas em silêncio no campo, entendeu que na atenção e percepção é que moravam às possibilidades de acesso do mundo daqueles sujeitos.

Diante dos silêncios, assim como Rocha (2012) que a fim de transcender os não-ditos, buscou na produção artística de esculturas das beatas, na composição dos altares domésticos narrativas outras do pensamento religioso, as fotografias, desenhos e composições em gavetas e 
sacolas me possibilitaram atentar aos outros fios dessa ontologia da doença entre as Irmãs. As imagens em suas aproximações e lacunas contribuem para adentrar e perceber o mundo múltiplo e espantoso. Como uma composição de cinzas com braseiros mais ou menos ardentes (Didi-Huberman, 2013) que aqui buscam prolongar a experiência sensível do campo ao leitor e à leitora.

\section{Referências bibliográficas:}

BOURDIEU, Pierre. 2007. Estruturas sociais incorporadas. In: BOURDIEU, Pierre. A distinção: crítica social do julgamento. São Paulo: Edusp, p. 435-446.

BOURDIEU, Pierre. 2006. O camponês e seu corpo. In: Revista de Sociologia e Politica, v. 26, p. 83-92.

CITRO, Silvia; LUCIO, Mayra; PUGLISI, Rodolfo. 2016. Hacia una perspectiva interdisciplinar sobre la corporeidad: los habitus, entre la filosofia, la antropologia y las neurociencias. In: MUÑIZ, Elsa. Heurísticas del cuerpo. Consideraciones desde América Latina. Ciudad de México: AM-Xochimilco - La Cifra Editorial, p. 97-129.

CSORDAS, Thomas. 2008. A corporeidade como um paradigma da Antropologia. In: CSORDAS, Thomas. Corpo/significado/cura. Porto Alegre: Editora UFRGS, p. 101-146.

DEBERT, Guita Grin. 2014. Arenas de conflito em torno do cuidado. In: Tempo Social, v. 26, n. 1. p. 34-45.

DIDI-HUBERMAN, Georges. 2013. Cascas. In: Revista Serrote, n. 13, p. 98-133.

DIDI-HUBERMAN, Georges. 2012. Quando as imagens tocam o real. In: Pós, v.2, n.4, p. 204219.

ENTLER, Ronald. 2012. Um pensamento de lacunas, sobreposições e silêncios. In: SAMAIN, Etienne (org). Como pensam as Imagens. Campinas: Editora da Unicamp, p. 133-150.

FAVRET-SAADA, Jeanne. 2009. Être affecté. In: FAVRET-SAADA, Jeanne. Désorcele. Paris: Éditions de l'Olivier, p. 145-161.

FERIANI, Daniela. 2017. Entre sopros e assombros: estética e experiência na doença de Alzheimer. Tese de doutorado. Campinas: Universidade Estadual de Campinas.

HUMMEL, Cornelia. 2017. Porter un regard photographique sur le vieillissement en couvent. Que disent les frontières mouvantes du "photographiable". In: Ethnographiques.org, v. 35, p. $1-18$.

INGOLD, Tim. 2015. Estar Vivo. Petrópolis: Vozes.

KONTOS, Pia C. 2004. Ethnographic reflections on selfhood, embodiment and Alzheimer's disease. In: Ageing \& Society, Cambridge, v. 24, p. 829-849.

LEIBING, Annette. 1999. Olhando para trás: os dois nascimentos da doença de Alzheimer e a senilidade no Brasil. In: Est. Interdiscipl. Envelhec., v. 1, p. 37-56. 
MARTÍN, Eloísa. 2002. Dos casos de transmisión devocional en la fiesta de la Virgen de Itatí. (Corrientes, Argentina). In: Anthropológicas, v. 13, n. 1, p. 35-46.

MAUSS, Marcel. 2003. Uma categoria do espírito humano: a noção de pessoa, a de "eu". In: MAUSS, Marcel. Sociologia e antropologia. São Paulo: CosacNaify, p. 367-397.

MERLEAU-PONTY, Maurice. 2004. Conversas-1948. São Paulo: Martins Fontes.

MOL, Annemarie. 2002. The body multiple: Ontology in medical practice. Durham: Duke University Press.

MURPHY, Ryan P. 2014. Promises unfulfilled: American religious sisters and gender inequality in the post-Vatican II Catholic Church. In: Social Compass, [s. 1.], v. 61, n. 4, p. 594-610.

NOVAES, Sylvia Caiuby. 2015. Entre arte e ciência: usos da fotografia pela antropologia. In: NOVAES, Sylvia C. (org.). Entre a arte e ciência: a fotografia na antropologia. São Paulo: Ed. Edusp, p. 9-20.

PUGLISI, Rodolfo. 2019. Etnografía y participación corporal. Contribuciones metodológicas para el trabajo de campo. In: Revista Latinoamericana de Metodología de la Investigación Social, Argentina, v. 17, p. 20-35.

ROBBINS, JOEL. 2011.Transcendência e Antropologia do Cristianismo:Linguagem, mudança e individualismo. In: Religião e Sociedade, v. 31, n. 1, p. 11-31.

ROCHA, Ewelter de Siqueira. 2012. Vestígios do Sagrado: uma etnografia sobre formas e silêncios. Tese de doutorado. São Paulo: Universidade de São Paulo.

VIANNA, Luciano V. D. G. 2013. Fragmentos de pessoa e a vida em demência: etnografia dos processos demências em torno da doença de Alzheimer. Dissertação de mestrado. Porto Alegre: Universidade Federal do Rio Grande do Sul.

VILLELA, Alice. 2015. Quando a imagem é a pessoa ou a fotografia como objeto patogênico. In: NOVAES, Sylvia C. (org). Entre a arte e ciência a fotografia na antropologia. São Paulo: Ed. Edusp, p. 109-121.

SACKS, Oliver. 1997. Tempo de despertar. São Paulo: Companhia das letras.

SAMAIN, Etienne. (org.). 2012. As imagens não são bolas de sinuca. In: SAMAIN, Etienne (org.). Como pensam as Imagens. Campinas: Editora da Unicamp, p. 21-40.

SOUZA, Iara Maria de Almeida. 2015. A noção de ontologias múltiplas e suas consequências políticas. In: Ilha Revista de Antropologia, v. 17, n. 2, p. 49-73.

sobre a autora

\section{Leticia Vicentin}

Mestranda pelo Programa de Pós-Graduação em Antropologia Social do Instituto de Filosofia e Ciências Humanas da Universidade Estadual de Campinas, com a pesquisa "Vida religiosa consagrada feminina e velhice dependente: uma 
etnografia dos arranjos diários em torno do cuidado'. Graduada em Ciências Sociais pela mesma universidade.

Contribuição de Autoria: Não se Aplica

Financiamento: A pesquisa que deu origem ao artigo foi financiada com recursos do Serviço de Apoio ao Estudante (SAE) da Universidade Estadual de Campinas por meio do Programa Institucional de Bolsas de Iniciação Científica do CNPq.

Recebido em 27/07/2020

Aceito para publicação em 16/04/2021 